\title{
Estimating Salary Compression in an ARL Institution: A University of Colorado at Boulder Case Study
}

\author{
Scott Seaman
}

\begin{abstract}
Salary compression is the narrowing of the pay differentials between people in the same job but with widely varying years of experience. Within academics, the most commonly asserted cause for salary compression is that of a labor shortage. When institutions compete in a job market with more vacancies than candidates, salaries for vacant positions increase faster than salaries for filled positions. As resources are directed at recruiting new hires rather than annual merit increases, productive senior staff find themselves earning similar salaries as new hires. While this has been common in disciplines such as business, nursing, and engineering, there is also anecdotal evidence that the conditions may have existed for this to happen in librarianship during the late 1990s. This case study defines salary compression, reviews the context in which it may arise, and discusses those conditions in which compression may be beneficial or may be detrimental, and examines the statistical tools used to detect evidence of compression within an organization. Multiple regression analysis is used to determine if there is evidence of salary compression among the librarians at the University of Colorado at Boulder.
\end{abstract}

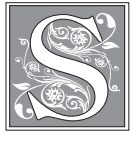
alary inequity, lower pay for similar work, has been a persistent issue in academic literature since the 1970s. Universities have commissioned thousands of studies to identify wage gaps and propose solutions for unexplained salary differences. While methodologies have evolved, each of these studies has compared individuals in similar positions against one or more variables to reveal any unexplainable salary differences. Within academic libraries, hundreds of pay equity studies have been performed in the past several decades. Gender, race, market, and even performance have been subjects of inequity studies. More recently, time in service has become an issue that is peculiar to academics. Inequity can be subtle, unintentional, masked by any number of variables, and detrimental to the successful functioning of an organization.

Most librarians are familiar with gender- and race-based salary inequity: that is, paying different salaries to differ- 
ent races or genders for the same work. There are, however, other kinds of salary inequity that can be equally demoralizing. Recently, some librarians with many years of service have perceived new hires with far less experience to have salaries similar to their own. They argue that such compression of the salary ranges between new hires and long-term librarians devalues long service and encourages turnover. While not age discrimination, salary compression is a kind of longevity discrimination or, as one observer described it, a "loyalty tax." 1

There is data that could be interpreted to support the existence of salary compression among midcareer librarians. With library vacancies exceeding qualified candidates, limited salary resources are diverted to make higher offers to new hires at the expense of annual merit increases. Figure 1 demonstrates how percentage increases in entry-level salaries have outpaced percentage increases for librarians' annual salary increases for nearly a decade. Between 1994 and 2004, academic research library (ARL) entry-level salaries increased by nearly 33 percent, while median salary increases rose by only 28 percent. $^{2}$ It is reasonable, therefore, to argue that, with entry-level salaries rising faster than established salaries, new hires could be compressing the salaries of more experienced librarians.

But a 2005 study of ARL position classifications found no evidence that entry-level salaries are compressing those of mid- or long-career librarians. Instead, the study found evidence that, for certain positions (heads of reference, heads of acquisitions, assistant directors, and others), those with 16 to 19 years of experience were compressing those with 24 to 27 years of experience. Senior career ARL librarians, therefore, suffer salary compression to the same degree as other academic disciplines but from their midcareer colleagues rather than from entry-

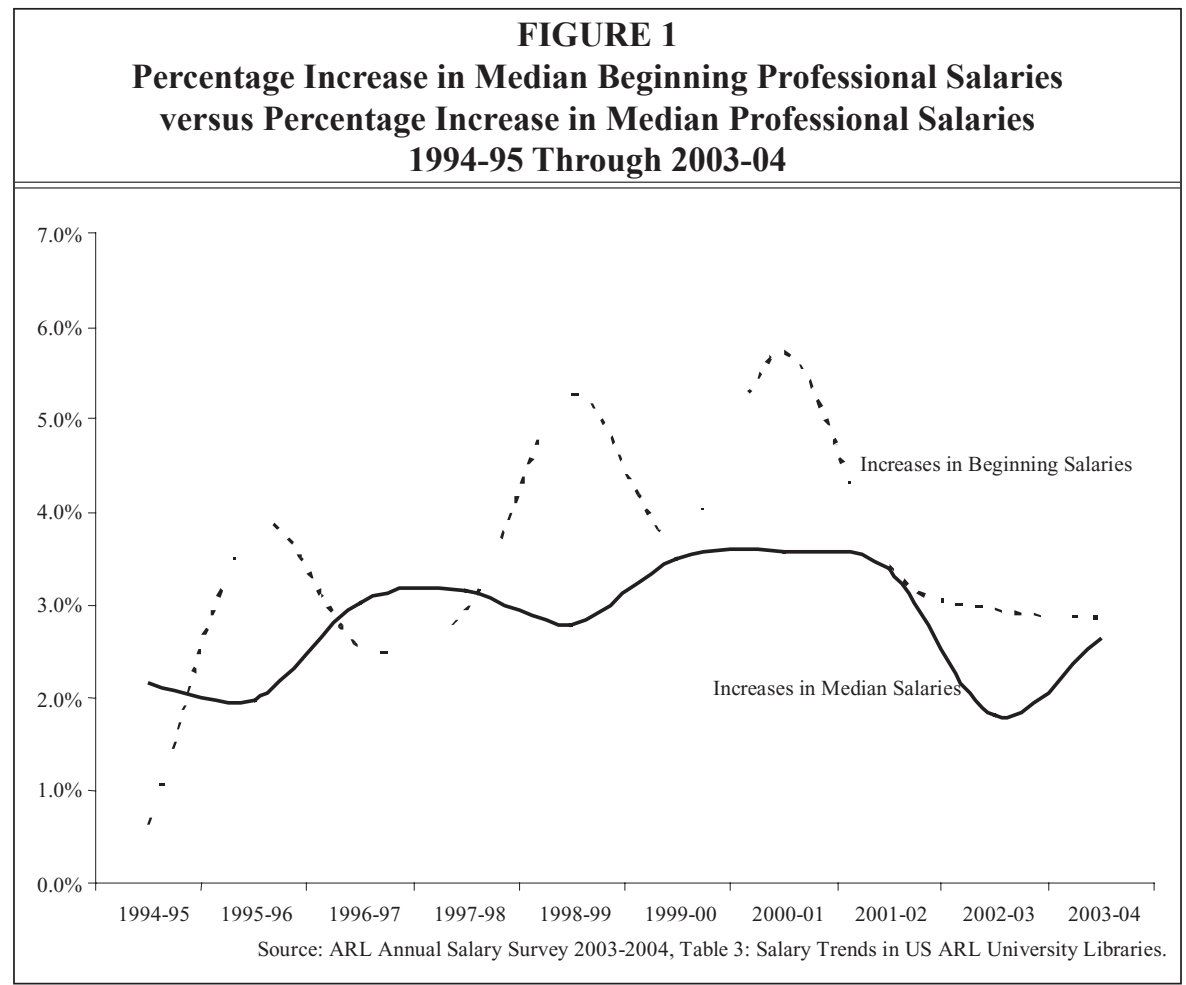


level hires. ${ }^{3}$ But evidence of compression in national data, regardless of what career level, is not indicative of what might be happening within a particular library.

The purpose of this paper is to present a case study of salary compression analysis for a medium-sized academic research library. Regression analysis is used to predict salaries based upon years in the profession while holding constant for administrative assignments and research productivity. The study is presented in such a way that it can be duplicated in other libraries.

\section{Literature Review}

To Julie Snyder, salary compression results when compensation is not based on longevity in a job, organization, or profession. ${ }^{4}$ According to Richard Huseman, salary compression results when "junior employees are compensated at approximately the same rate as senior employees." ${ }^{5}$ Recognizing that compression can occur among any ranks, Nancy Bereman and Mark Lengnick-Hall broaden their definition to "the narrowing over time of the pay differentials between people in the same job." ${ }^{\prime \prime}$

Within academics, the most commonly asserted cause for salary compression is that of a labor shortage. That is, faculty vacancies exceed job seekers. To fill critical vacancies, institutions adjust salary offers upward. Limited salary resources, however, prevent those institutions from providing equal salary adjustments to faculty already on staff. As a result, the difference in salary between new hires and senior faculty narrows. In extreme cases, junior faculty are hired with salaries that are similar or even exceed those with many years of experience at the institution. Among senior faculty, the hiring of new, often junior, faculty at nearly the same salaries as senior faculty is asserted as a problem leading to reduced morale, lower productivity, and higher turnover. ${ }^{7}$

Such market dynamics, it has been argued, have had devastating results within certain disciplines during the 1980s and 1990s. Business schools, for example, experienced this phenomenon most frequently. The explosion of undergraduate and M.B.A. programs during that time required additional faculty. Shortages of recent Ph.D. graduates sent entry-level salaries to stratospheric levels and forced departments to reallocate limited salary resources into meeting market demands for new hires rather than increasing the salaries of existing faculty. Senior or midcareer faculty who were able to relocate to another institution received large salary increases. Faculty who could not relocate and remained at their institution-even though they had more experience-found their salaries to be lower than those recently hired. ${ }^{8}$

Such phenomena may not be isolated to disciplines affected by market extremes such as business, nursing, or engineering. Michael Ransom's 1993 longitudinal study used national data from the 1960s through the 1980s from nearly all academic disciplines - although not librarianship - and found salary compression in nearly every field and significant compression among senior faculty in literature, history, and economics. With large research universities being relatively rare and geographically dispersed, Ransom observed that tenured faculty in specialized disciplines have few choices in the labor market. Consequently, he speculated that senior faculty have little leverage in annual salary negotiations. ${ }^{9}$

Another national study of 28,000 faculty from a variety of disciplines - this time including librarians-compared junior and senior salaries for evidence of salary compression. When researchers examined data across all disciplines, no evidence for salary compression was found to be present. When they examined disciplineby-discipline, though, compression was found in business and economics. Librarians were combined into a category that mixed several applied disciplines such as journalism, architecture, and library science together. Further, only librarians 
holding faculty titles were included in the data. Those without a professorial rank, more than half of ARL librarians, were excluded. From such limited data, it is impossible to conclude anything about salary compression among academic librarians. ${ }^{10}$

Only one study has specifically addressed salary compression among academic librarians. Using data from the 2003-2004 ARL Annual Salary Survey, that study used a ratio analysis technique to the sixteen formally defined ARL position classifications. For each position classification (including cataloger, functional specialist, circulation department head), average national salaries were analyzed at the entry-, mid-, and senior-career levels for signs of compression. Evidence that mid-career salaries were compressing senior-career salaries was found among several position classifications including associate directors, assistant directors, and department heads of reference. It is significant to note that the study found no evidence that entry-level librarian salaries were compressing midcareer salaries. Yet, evidence of compression at a national level does not mean it is present at a particular library; and, moreover, such a limited study could not offer any explanation as to why some positions exhibited compression but not others. ${ }^{11}$

Any argument for the presence of salary compression should be viewed with skepticism. Many salary compression studies fail to consider that salary differentials between junior and senior faculty may be explained by factors other than market economics. Productivity, workload, educational attainment, as well as any new skills that recent hires bring impact salary and are difficult to quantify in statistical models. How variables are defined, the composition of the comparison groups, and what, if any, constants are included influence the results, and subtle variations in definition can bias the results. While this is true of any statistical study, it is particularly a problem in compression studies where authors may have an interest in the conclusions. Whether salary inequity is found to exist, however, depends less on the methodology chosen than on how the comparison groups are defined.

In addition, it is important to note that salary compression is not inevitably harmful to an academic department or library. There can be good reasons that those with relatively less experience receive high salaries. Paying premiums to attract librarians with new skill sets, compensating those with unique assignments, or negotiating higher salaries to retain critical librarians are all appropriate and could rationally create compression. Finally, there will always be over- and underachievers in every library. Their long-term productivity patterns will legitimately produce salary compression. A statistical model may, therefore, demonstrate the existence of salary compression without there being any real inequities within the salary structure.

\section{Regression Analysis}

With the potential for overstating or misinterpreting salary compression within any population, researchers must be cautious in selecting the proper analytical tool and defining the variables to be analyzed. Multiple linear regression is the statistical tool most often selected when detailed information is available for the subjects being studied. ${ }^{12}$ Using regression, researchers can analyze a single dependent variable to determine how it is influenced by several independent variables. For example, athletic performance (the dependent variable) can be predicted using such factors as age, height, and weight (the independent variables). Given a population of fifty athletes whose performance, age, height, and weight are known, a statistical comparison can be made to predict the performance of an untested athlete based on that athlete's age, height, and weight. Similarly, librarians' salaries (the dependent variable) can be predicted using such factors as years of experience, administrative responsibil- 
ity, educational attainment, or librarians' rank (the independent variables). If the predicted salary matches the actual salary, then no salary compression is present. If the predicted salary is lower than the actual salary, then salary compression may be present.

While virtually anything that can be quantified can be a variable in regression analysis, care must be taken in selecting variables that are appropriate and accurate; otherwise, the technique may be pushed beyond the limits to which it can be credibly applied. For salary compression studies, the dependent variable is nearly always the 12 -month, 100 percent full-time librarian's salary, excluding any temporary stipends. The independent variable must be some measure of experience whether it is years in the profession, years at the institution, or years since terminal degree. Other independent variables that may have a significant impact on salary, such as administrative assignments or productivity, can be included in the analysis to bring more accuracy to the results.

One advantage of using multiple linear regression analysis is that it permits inclusion of several additional independent variables that may help refine the analysis. Previous studies often include six or even more independent variables. Independent variables should, however, be added to the model with extreme caution, as they can inadvertently introduce hidden bias. For example, faculty rank or time in rank is sometimes included in compression studies as a proxy for career performance. ${ }^{13}$ It has been demonstrated, however, that rank tends to mask any gender differences in the promotion and tenure process, making this a highly suspect measure of performance. ${ }^{14}$ Careless inclusion of faculty rank as an independent variable could weaken an analysis rather than strengthen it.

A dizzying array of other independent variables has been included in studies to approximate the presence or absence of certain characteristics. One study in- cluded an independent variable for any faculty who had received a recent outside offer under the reasoning that the department had to competitively match the offer, which would increase the salary. ${ }^{15}$ A recent national study reasoned that the number of times a faculty member had changed positions would increase the salary because, with each change, salary would increase to market rather than being held back by less lucrative local merit increases. ${ }^{16}$ Similarly, another study included an independent variable to differentiate faculty hired with tenure as opposed to those who had earned tenure and remained at the institution under study. The assumption was that those hired with tenure would be receiving a higher salary based on the market, while those with long experience would be receiving a lower salary based on local merit awards. ${ }^{17}$ Finally, there have been studies that attempt to introduce productivity surrogates through some combination of publication counts, citation analysis, number of Ph.D. dissertations supervised, teaching evaluations, service as department chair, and successful grant applications. ${ }^{18}$ Whether inclusion of any such variables improves the accuracy of analysis depends entirely upon their impact on salaries. Including a variable measuring all librarians' scholarly productivity is only useful if scholarly activities are rewarded through the salary structure. Similarly, variables accounting for faculty rank or educational attainment are only useful if the salary structure rewards are based on those criteria.

Robert Toutkoushian developed a widely replicated five-step model using regression analysis to determine faculty salary compression at the department level. ${ }^{19}$ This method tests the average difference between predicted and actual salaries of junior faculty in which the predicted salaries are derived from regression analysis that assumes they are senior faculty. Few libraries, however, can fulfill the data requirements of Toutkoushian's model. It requires at least three senior 
faculty who have spent their entire career in the department being studied and have maintained the same general assignment. While relatively common in teaching departments, it is an unusual library that has multiple librarians with twenty-five years of experience who have served only at that institution and in the same position.

\section{Population}

For the purposes of this study, salary compression is defined as resulting from any new hire's salary being nearly equal to that of senior faculty when adjusted for length of service at the institution. Rather than using the Toutkoushian method, a more typical regression analysis-one that uses multiple regression-was used for this study. An estimate for salary compression was based on the dependent variable, the 2005-2006 salary, and three independent variables: years at CU-Boulder Libraries, administrative responsibility, and compensation for scholarly productivity. The three independent variables were carefully chosen because they significantly impact salaries in the University Libraries.

The design of this regression analysis is to predict values for administrative responsibility, above-average scholarly productivity, and each year of experience at CU-Boulder. Together, those three variables comprise an individual librarian's predicted salary. The actual salary of an individual may, however, be higher or lower than the salary predicted by the regression analysis. If the salary is higher than predicted, the librarian may be more productive than expected, have negotiated a better starting salary than is typical of the population, have recently received a retention offer, or be highly rewarded for administrative responsibilities. If a librarian with a high number of years of service has lower than predicted salary, however, it may be evidence of salary compression.

Table 1 details the population and variables included in this study. Observation number substitutes for the name of the faculty member. There are a total of forty librarians included in the population. All permanent librarians were included, with salaries for part-time librarians equated to those with full-time appointments. No temporary stipends, such as for serving as an interim department head, were included in the salary calculation. Librarians at all ranks - senior instructors and assistant, associate, and full professors-were included. The Libraries' dean and associate deans were excluded from the analysis because of their unusually high administrative responsibilities.

The population of forty librarians was separated into two groups, one being the twenty-seven tenure-track and tenured librarians with the other being the thirteen non-tenure-track librarians. An important difference between the two groups is that the non-tenure-track, classed as senior instructors, are not required to be scholarly productive. The annual merit process, however, rewards scholarship, and those who have been productive have been awarded a larger proportion of the salary pool over the past decade. Although senior instructors are encouraged toward scholarship, the tenurestream librarians have regularly proven to be more productive. This has caused a tiered salary structure, with the scholarly productive having annual higher compensation. Combining tenure-stream and non-tenure-stream into a single analysis would, therefore, tend to exaggerate the appearance of any salary compression among the non-tenure-stream when, in fact, it is a structural component of the reward system.

\section{Independent Variables}

Defining the key independent variableexperience-requires careful consideration. There are several subtle definitions of experience, each influencing the final results in different ways. Teaching departments commonly calculate experience by counting years since terminal degree was earned. A widely acknowledged limita- 


\begin{tabular}{|c|c|c|c|c|}
\hline \multicolumn{5}{|c|}{$\begin{array}{c}\text { TABLE } 1 \\
\text { Librarian Profiles 2005-06 }\end{array}$} \\
\hline $\begin{array}{c}\text { Tenure-Stream } \\
\text { Librarians } \\
\text { Observation } \\
\text { Number }\end{array}$ & $\begin{array}{c}\text { Years at } \\
\text { CU-Boulder } \\
\text { Libraries } \\
(\mathbf{2 0 0 5 - 0 6 )}\end{array}$ & $\begin{array}{c}\text { Administrative } \\
\text { Responsibility } \\
\begin{array}{c}(0=\text { No, } 1=\text { Yes, } \\
2=\text { High })\end{array}\end{array}$ & $\begin{array}{l}\text { Above-Average } \\
\text { Scholarly } \\
\text { Compensation } \\
(0=\text { No, } 1=\text { Yes })\end{array}$ & $\begin{array}{l}\text { Actual Salary } \\
\quad(2005-06)\end{array}$ \\
\hline 1 & 3 & 0 & 0 & $\$ 42,141$ \\
\hline 2 & 14 & 1 & 0 & $\$ 77,150$ \\
\hline 3 & 4 & 0 & 1 & $\$ 44,480$ \\
\hline 4 & 16 & 1 & 1 & $\$ 77,153$ \\
\hline 5 & 1 & 0 & 0 & $\$ 41,061$ \\
\hline 6 & 9 & 0 & 0 & $\$ 51,049$ \\
\hline 7 & 12 & 1 & 1 & $\$ 71,799$ \\
\hline 8 & 3 & 0 & 1 & $\$ 44,427$ \\
\hline 9 & 12 & 1 & 1 & $\$ 70,707$ \\
\hline 10 & 3 & 0 & 0 & $\$ 40,895$ \\
\hline 11 & 10 & 1 & 1 & $\$ 69,648$ \\
\hline 12 & 9 & 0 & 1 & $\$ 57,332$ \\
\hline 13 & 4 & 0 & 1 & $\$ 45,522$ \\
\hline 14 & 3 & 0 & 0 & $\$ 41,587$ \\
\hline 15 & 2 & 0 & 0 & $\$ 44,531$ \\
\hline 16 & 4 & 0 & 1 & $\$ 53,000$ \\
\hline 17 & 2 & 0 & 0 & $\$ 41,537$ \\
\hline 18 & 4 & 0 & 1 & $\$ 46,390$ \\
\hline 19 & 4 & 0 & 1 & $\$ 43,738$ \\
\hline 20 & 14 & 1 & 1 & $\$ 77,167$ \\
\hline 21 & 3 & 1 & 0 & $\$ 58,330$ \\
\hline 22 & 1 & 0 & 0 & $\$ 41,061$ \\
\hline 23 & 12 & 1 & 1 & $\$ 66,808$ \\
\hline 24 & 11 & 0 & 0 & $\$ 61,260$ \\
\hline 25 & 3 & 0 & 1 & $\$ 44,702$ \\
\hline 26 & 2 & 0 & 0 & $\$ 47,059$ \\
\hline 27 & 6 & 0 & 0 & $\$ 51,714$ \\
\hline $\begin{array}{c}\text { Senior } \\
\text { Instructor } \\
\text { Librarians } \\
\text { Observation } \\
\text { Number } \\
\end{array}$ & $\begin{array}{c}\text { Years at } \\
\text { CU-Boulder } \\
\text { Libraries } \\
(\mathbf{2 0 0 5 - 0 6 )}\end{array}$ & $\begin{array}{c}\text { Administrative } \\
\text { Responsibility } \\
\begin{array}{c}(0=\text { No, } 1=\text { Yes, } \\
2=\text { High })\end{array}\end{array}$ & $\begin{array}{c}\text { Above-Average } \\
\text { Scholarly } \\
\text { Compensation } \\
(0=\text { No, } 1=\text { Yes })\end{array}$ & $\begin{array}{l}\text { Actual Salary } \\
\quad(2005-06)\end{array}$ \\
\hline 1 & 16 & 1 & 0 & $\$ 60,667$ \\
\hline 2 & 25 & 0 & 0 & $\$ 55,788$ \\
\hline 3 & 20 & 1 & 0 & $\$ 66,376$ \\
\hline
\end{tabular}


Estimating Salary Compression in an ARL Institution 395

\begin{tabular}{|c|c|c|c|c|}
\hline \multicolumn{5}{|c|}{$\begin{array}{l}\text { TABLE } 1 \text { (CONTINUED) } \\
\text { Librarian Profiles 2005-06 }\end{array}$} \\
\hline $\begin{array}{c}\text { Senior } \\
\text { Instructor } \\
\text { Librarians } \\
\text { Observation } \\
\text { Number }\end{array}$ & $\begin{array}{c}\text { Years at } \\
\text { CU-Boulder } \\
\text { Libraries } \\
(\mathbf{2 0 0 5 - 0 6 )}\end{array}$ & $\begin{array}{c}\text { Administrative } \\
\text { Responsibility } \\
(0=\text { No, } 1=\text { Yes } \\
2=\text { High })\end{array}$ & $\begin{array}{l}\text { Above-Average } \\
\text { Scholarly } \\
\text { Compensation } \\
(0=\text { No, } 1=\text { Yes })\end{array}$ & $\begin{array}{l}\text { Actual Salary } \\
(2005-06)\end{array}$ \\
\hline 4 & 23 & 1 & 1 & $\$ 67,672$ \\
\hline 5 & 11 & 0 & 0 & $\$ 54,160$ \\
\hline 6 & 24 & 1 & 0 & $\$ 63,587$ \\
\hline 7 & 25 & 0 & 1 & $\$ 54,609$ \\
\hline 8 & 25 & 0 & 0 & $\$ 57,201$ \\
\hline 9 & 33 & 0 & 0 & $\$ 60,286$ \\
\hline 10 & 25 & 1 & 1 & $\$ 70,504$ \\
\hline 11 & 17 & 2 & 1 & $\$ 75,383$ \\
\hline 12 & 17 & 0 & 1 & $\$ 56,265$ \\
\hline 13 & 19 & 0 & 0 & $\$ 56,472$ \\
\hline
\end{tabular}

tion of this count is that faculty hired with a recent terminal degree might have lengthy previous teaching experience and considerable publication records. Starting salaries of such individuals are often much higher than those without similar experience. By counting only years since terminal degree, individuals with more experience and higher salaries will be grouped with those without experience and with lower salaries. This will overstate the presence of salary compression. Because many librarians have worked several years as post-MLS paraprofessionals, if years since terminal degree are used as the experience measure, salary compression will tend to be exaggerated because those with a high number of years since terminal degree will occupy lower salaried entry-level positions.

Another common measure of experience is years at the institution. This count may better isolate the impact of salary decisions that have happened at the institution in which the subjects are currently employed. Nicholas Twigg cautioned that counting years at the institution may also overstate compression. Recent hires, he points out, will include both low-salaried junior faculty as well as newly hired, highly paid senior faculty. Senior faculty high salaries may exaggerate the average salary of those with only a few years at the institution and the presence of compression. ${ }^{20}$ Another common measure of experience is a count of years in the profession. This counts the number of years engaged in teaching or librarianship regardless of when the terminal degree was received or when hired at the institution. This can be a complicated count if, as do many librarians, the individual has relevant paraprofessional experience or has worked in a related but nonacademic field. Determining an equitable accounting of such experience is often highly controversial and can undermine the credibility of the results. Whether any of these limitations is significant depends upon the local definition of salary compression and the characteristics of the individuals under study.

There can be no definitive rules as to how years of service should be determined. Instead, it should be a method that complements, rather than over- or understates, the local definition of salary compression. If salary compression 
is defined only as junior faculty salaries being nearly equal to those of senior faculty, then years at institution would be inappropriate, as this tends to overstate compression between new hires and those with long service at the institution. If, however, salary compression is defined as resulting from any new hire's salary being nearly equal to that of senior faculty, then using years at institution would be appropriate. The characteristics of the individuals at the particular institution can also help determine how the count of years of experience can best be made. If, for example, there are very few recent hires of senior-level faculty or if those who have been recently hired can be excluded from the population, then using years at institution could be appropriate.

In any salary compression study, the way in which years of service are measured will have the most impact on determining salary compression. There are several ways to measure years of service with no single method being universally correct. Instead, it depends upon local circumstances and the population under consideration. Using the most common count, years since terminal degree, did not work in the University Libraries because several librarians had long gaps in their careers. Because these librarians have not had the years of experience needed to build their salaries, using this measure would tend to exaggerate the appearance of compression. Similarly, counting years in the profession, another common measure, proved too complicated as several librarians had worked with library vendors, public libraries, or international agencies. Whether experience in such fields was comparable to an academic library created debate, and how such experience impacted an individual's salary was unclear.

While those two counts proved problematic, counting only the number of years at the University Libraries proved to be a better fit. One characteristic of the population of forty librarians was that the average length of service at the University
Libraries was relatively high-eleven years. While there were several relatively new hires, only two started with salaries higher than the median. With a population having served so many years at the same institution, it could be reasonably presumed that counting years of service with the University Libraries would adequately capture any compression inherent in the salary structure. Consequently, it was concluded that a count of years of service at the University Libraries would be used as the primary independent variable.

Faculty salaries increase as administrative duties increase. To account for this, a variable indicating whether a faculty member was a department head was included. Administrative responsibility was initially determined by administrative titles such as department chair or unit head. Titles, however, proved to be unrepresentative of actual responsibilities and salaries. Several librarians with significant supervisory or budgetary authority did not have administrative titles. Several with administrative titles had few or no programmatic responsibilities. While titles were not related to responsibilities, salaries positively correlated to administrative responsibilities. It was important, therefore, to account for administrative responsibility in the compression study. The researcher reviewed each position description to determine if a librarian had significant programmatic authority such as policy, budgeting, supervision, or planning. Those determined significant were coded as 1 in the regression model. In a single case, a librarian managing two science branch libraries was coded as a 2 for unusually high administrative responsibilities. Temporary administrative appointments were not considered for the purposes of the analysis.

Research productivity is compensated at the University Libraries through the annual salary merit review process. The Faculty Personnel Committee scores each librarian on that year's scholarly activity, and higher scores calculate into higher 
total annual merit increases. Research productivity can make up a large portion of a librarian's total annual merit increase, and those who consistently do well in research earn significantly higher salaries. Tenure-stream librarians, as a group, receive an average of 40 percent of their annual salary increase as a consequence of research activities. Senior instructors, who are not required to perform research, receive an average of only 13 percent of their annual salary increase from scholarly activities. The disparity between the senior instructors' and tenure-stream librarians' research required that those two populations be separated for purposes of this study. Otherwise, the senior instructors' lower salaries, which are a result of lower research activity, would exaggerate the existence of any compression when measured against the tenure-stream librarians' salaries. But even within the two populations, there were wide ranges of research productivity. For example, tenure-stream librarians received 38.8 percent of their salary increase due to scholarship in 1998-1999. But some individual percentages were as high as 53 percent or as little as 23 percent. Without isolating and adjusting for this, it would be impossible to determine if a librarian was suffering from salary compression

\begin{tabular}{|c|c|c|c|c|c|}
\hline Senior Ins & tructor Libi & $\begin{array}{r}\text { TAB } \\
\text { arians Regr }\end{array}$ & $\begin{array}{l}\text { E } 2 \\
\text { ssion Statist }\end{array}$ & cs and ANO & A Table \\
\hline REGRESSION & STATISTICS & & & & \\
\hline Multiple R & 0.98 & & & & \\
\hline R Square & 0.96 & & & & \\
\hline $\begin{array}{l}\text { Adjusted R } \\
\text { Square }\end{array}$ & 0.95 & & & & \\
\hline Standard Error & $\$ 2,803.10$ & & & & \\
\hline Observations & 27 & & & & \\
\hline ANOVA Table & & & & & \\
\hline & $d f$ & $S S$ & $M S$ & $F$ & $\begin{array}{c}\text { Significance } \\
F\end{array}$ \\
\hline Regression & 3 & 4127358223 & 1375786074 & 175.09 & $5.61463 \mathrm{E}-16$ \\
\hline Residual & 23 & 180719614.3 & 7857374.537 & & \\
\hline Total & 26 & 4308077837 & & & \\
\hline & Coefficients & $\begin{array}{l}\text { Standard } \\
\text { Error }\end{array}$ & t Stat & P-value & \\
\hline Intercept & $\$ 39,468.13$ & $\$ 1,028.79$ & 38.36 & $2.35354 \mathrm{E}-22$ & \\
\hline $\begin{array}{l}\text { Year at } \\
\text { CU-Boulder } \\
\text { Libraries }\end{array}$ & $\$ 1,714.52$ & $\$ 183.19$ & 9.36 & $2.62718 \mathrm{E}-09$ & \\
\hline $\begin{array}{l}\text { Administrative } \\
\text { Responsibility }\end{array}$ & $\$ 11,709.05$ & $\$ 1,791.98$ & 6.53 & $1.14618 \mathrm{E}-06$ & \\
\hline $\begin{array}{l}\text { Above-Average } \\
\text { Scholarly } \\
\text { Compensation }\end{array}$ & $-\$ 17.63$ & $\$ 1,159.55$ & -0.02 & 0.988000156 & \\
\hline
\end{tabular}


or years of poor research productivity. Therefore, an independent variable was added to the regression model adjusting for unusually high salary increases due to research. A significant portion of this project, consequently, involved estimating what portion of salary increases was due to scholarly productivity.

Calculating the portion of total salary increases attributable to scholarly productivity proved difficult. After several unsuccessful attempts, a method was developed that identified those librarians who had received above-average compensation for research for three sample years - 1998-1999, 2000-2001, and 2003-2004. Only three years were chosen because of the limited availability of raw data and the complexity of the process. Calculations were performed for each librarian to determine the percentage of his/her salary increase due to scholarly activities. An overall average was calculated, and those who scored higher than the overall average in two of the three years were assumed to be consistently better rewarded for their scholarship. Those librarians identified as being better compensated due to research were coded with a 1 for the independent variable

\begin{tabular}{|c|c|c|c|c|c|}
\hline \multicolumn{6}{|c|}{$\begin{array}{c}\text { TABLE } 3 \\
\text { Senior Instructor Librarians Regression Statistics and ANOVA Table }\end{array}$} \\
\hline \multicolumn{6}{|c|}{ REGRESSION STATISTICS } \\
\hline Multiple R & 0.96 & & & & \\
\hline R Square & 0.92 & & & & \\
\hline $\begin{array}{l}\text { Adjusted R } \\
\text { Square }\end{array}$ & 0.89 & & & & \\
\hline Standard Error & $\$ 2,240.48$ & & & & \\
\hline Observations & 13 & & & & \\
\hline \multicolumn{6}{|l|}{ ANOVA Table } \\
\hline & $d f$ & $S S$ & $M S$ & $F$ & $\begin{array}{l}\text { Significance } \\
\quad F\end{array}$ \\
\hline Regression & 3 & \begin{tabular}{|l|}
502158354.7 \\
\end{tabular} & 167386118.2 & 33.35 & $3.33124 \mathrm{E}-05$ \\
\hline Residual & 9 & 45177791.57 & 5019754.619 & & \\
\hline \multirow[t]{2}{*}{ Total } & 12 & 547336146.3 & & & \\
\hline & Coefficients & $\begin{array}{l}\text { Standard } \\
\text { Error }\end{array}$ & t Stat & $P$-value & \\
\hline Intercept & $\$ 49,747.52$ & $\$ 2,764.92$ & 17.99 & $2.30324 \mathrm{E}-08$ & \\
\hline $\begin{array}{l}\text { Year at } \\
\text { CU-Boulder } \\
\text { Libraries }\end{array}$ & $\$ 277.73$ & $\$ 117.48$ & 2.36 & 0.042319583 & \\
\hline $\begin{array}{l}\text { Administrative } \\
\text { Responsibility }\end{array}$ & $\$ 9,503.31$ & $\$ 1,057.88$ & 8.98 & 8.66804E-06 & \\
\hline $\begin{array}{l}\text { Above- } \\
\text { Average } \\
\text { Scholarly } \\
\text { Compensation }\end{array}$ & $\$ 1,593.06$ & $\$ 1,352.58$ & 1.18 & 0.269084116 & \\
\hline
\end{tabular}


“Above-Average Scholarly Compensation" in the regression model.

\section{Analysis}

The multiple regression was performed using the statistical analysis package of Microsoft Excel at a 0.05 significance level. Table 2 presents the regression statistics and the Analysis of Variance (ANOVA) table for the senior instructors, and table 3 presents the same for the tenure-stream faculty.

Regression statistics for both the senior instructors and tenure-stream librarians exhibit strong r-squares (0.92 and 0.96 respectively) with relatively small standard errors. Consequently, the variables of years at CU Libraries, administrative responsibility, and scholarly compensation account for 92 percent of senior instructor salaries and 96 percent of tenure-stream librarians' salaries. The remaining 8 percent for senior instructors and 4 percent for tenure-stream faculty could, potentially, be attributed to salary compression. That so little is unexplained, however, suggests that salary compression is not a pervasive problem within the University Libraries. Had either the senior instructors or tenure-stream faculty exhibited large unexplained gaps-exhibited by low r-square numbers - this could have indicated evidence for widespread salary compression. But with such an overwhelming proportion of salaries explained by years of service, administration, and scholarly productivity, there is very little evidence to support a pattern of salary compression within this population.

A common way of interpreting the coefficients on tables 2 and 3 is that the typical tenure-stream librarian is hired at $\$ 39,468$. For each year in the University Libraries, the typical tenure-stream librarian's salary increases by $\$ 1,714$. Accepting an administrative position increases a tenure-stream librarian's salary an average of $\$ 11,709$. For both the variables of "Years at CU Libraries" and "Administrative Responsibility," the t-statistics are relatively high, which suggests high accuracy. Less accurate, however, is the scholarly compensation coefficient. At $-\$ 17.63$, the coefficient implies that tenurestream librarians are slightly penalized for above average scholarly production. The low t-statistic indicates that this aspect of tenure-stream librarians' salaries is not adequately captured in this model. As the standard error for this variable is $\$ 1,159$, the librarian could be receiving a one-time bonus of about $\$ 560$ or losing as much as $\$ 579$ for productivity. Nonetheless, with an r-square of 0.96 , the overall model is unusually accurate and strongly suggests the absence of salary compression among the tenure-stream librarians.

As noted above, the overall senior instructor regression statistics are also highly accurate, with 92 percent of their salaries explained by the three variables, leaving very little unexplained salary that could be attributed to salary compression. But the coefficients exhibit subtly different characteristics than those of the tenurestream librarians. The "Administrative Responsibility" variable is very strong, suggesting that, as a group, the senior instructors have become extremely successful administrators within the Libraries. That their higher salaries are largely gained through administrative efforts rather than scholarly pursuits is supported through the relatively low t-statistic for the "Scholarly Compensation" variable. Similarly, each "Year at CU Libraries" adds only \$277 to a senior instructor's salary. The low t-statistic indicates that some other factor-unaccounted for in the regression model-is impeding the accuracy of this variable. This is likely to be the senior instructor's length of service. The median years of service for senior instructors are 23, while the median years for tenure-stream librarians are only four. Such length of service is not controlled for in the regression model, and the inevitable salary consequences could be the cause of the low t-statistic associated with this variable. As it stands, the low t-statistic associated with this variable indicates poor accuracy and precludes using it to 
speculate as to salary compression for the senior instructor population.

While there is little evidence for pervasive salary compression, isolated individuals may suffer from salary compression within either of the two populations. Table 4 depicts the residuals for each librarian as calculated through the regression statistics. Residuals are the difference between the predicted salary and the actual salary. For example, the regression model predicts that tenurestream librarian observation number 23 (from table 1) who has twelve years at

\begin{tabular}{|c|c|c|c|c|c|}
\hline \multicolumn{6}{|c|}{$\begin{array}{c}\text { TABLE } 4 \\
\text { Tenure-Stream and Senior Instructor Librarians } \\
\text { Salary Compression Residuals }\end{array}$} \\
\hline \multicolumn{3}{|c|}{$\begin{array}{c}\text { Tenure-Stream Regression } \\
\text { Residual Output }\end{array}$} & \multicolumn{3}{|c|}{$\begin{array}{c}\text { Senior Instructor Regression } \\
\text { Residual Output }\end{array}$} \\
\hline Observation & $\begin{array}{l}\text { Predicted } \\
\text { Salary }\end{array}$ & Residuals & Observation & $\begin{array}{l}\text { Predicted } \\
\text { Salary }\end{array}$ & Residuals \\
\hline 1 & $\$ 44,611.69$ & $-\$ 2,470.69$ & 1 & $\$ 63,694.47$ & $-\$ 3,027.47$ \\
\hline 2 & $\$ 75,180.46$ & $\$ 1,969.54$ & 2 & $\$ 56,690.72$ & $-\$ 902.72$ \\
\hline 3 & $\$ 46,308.58$ & $-\$ 1,828.58$ & 3 & $\$ 64,805.39$ & $\$ 1,570.61$ \\
\hline 4 & $\$ 78,591.86$ & $-\$ 1,438.86$ & 4 & $\$ 67,231.63$ & $\$ 440.37$ \\
\hline 5 & $\$ 41,182.65$ & $-\$ 121.65$ & 5 & $\$ 52,802.52$ & $\$ 1,357.48$ \\
\hline 6 & $\$ 54,898.81$ & $-\$ 3,849.81$ & 6 & $\$ 65,916.30$ & $-\$ 2,329.30$ \\
\hline 7 & $\$ 71,733.79$ & $\$ 65.21$ & 7 & $\$ 58,283.77$ & $-\$ 3,674.77$ \\
\hline 8 & $\$ 44,594.06$ & $-\$ 167.06$ & 8 & $\$ 56,690.72$ & $\$ 510.28$ \\
\hline 9 & $\$ 71,733.79$ & $-\$ 1,026.79$ & 9 & $\$ 58,912.54$ & $\$ 1,373.46$ \\
\hline 10 & $\$ 44,611.69$ & $-\$ 3,716.69$ & 10 & $\$ 67,787.08$ & $\$ 2,716.92$ \\
\hline 11 & $\$ 68,304.75$ & $\$ 1,343.25$ & 11 & $\$ 75,068.57$ & $\$ 314.43$ \\
\hline 12 & $\$ 54,881.18$ & $\$ 2,450.82$ & 12 & $\$ 56,061.95$ & $\$ 203.05$ \\
\hline 13 & $\$ 46,308.58$ & $-\$ 786.58$ & 13 & $\$ 55,024.35$ & $\$ 1,447.65$ \\
\hline 14 & $\$ 44,611.69$ & $-\$ 3,024.69$ & & & \\
\hline 15 & $\$ 42,897.17$ & $\$ 1,633.83$ & & & \\
\hline 16 & $\$ 46,308.58$ & $\$ 6,691.42$ & & & \\
\hline 17 & $\$ 42,897.17$ & $-\$ 1,360.17$ & & & \\
\hline 18 & $\$ 46,308.58$ & $\$ 81.42$ & & & \\
\hline 19 & $\$ 46,308.58$ & $-\$ 2,570.58$ & & & \\
\hline 20 & $\$ 75,162.83$ & $\$ 2,004.17$ & & & \\
\hline 21 & $\$ 56,320.74$ & $\$ 2,009.26$ & & & \\
\hline 22 & $\$ 41,182.65$ & $-\$ 121.65$ & & & \\
\hline 23 & $\$ 71,733.79$ & $-\$ 4,925.79$ & & & \\
\hline 24 & $\$ 58,327.85$ & $\$ 2,932.15$ & & & \\
\hline 25 & $\$ 44,594.06$ & $\$ 107.94$ & & & \\
\hline 26 & $\$ 42,897.17$ & $\$ 4,161.83$ & & & \\
\hline 27 & $\$ 49,755.25$ & $\$ 1,958.75$ & & & \\
\hline
\end{tabular}




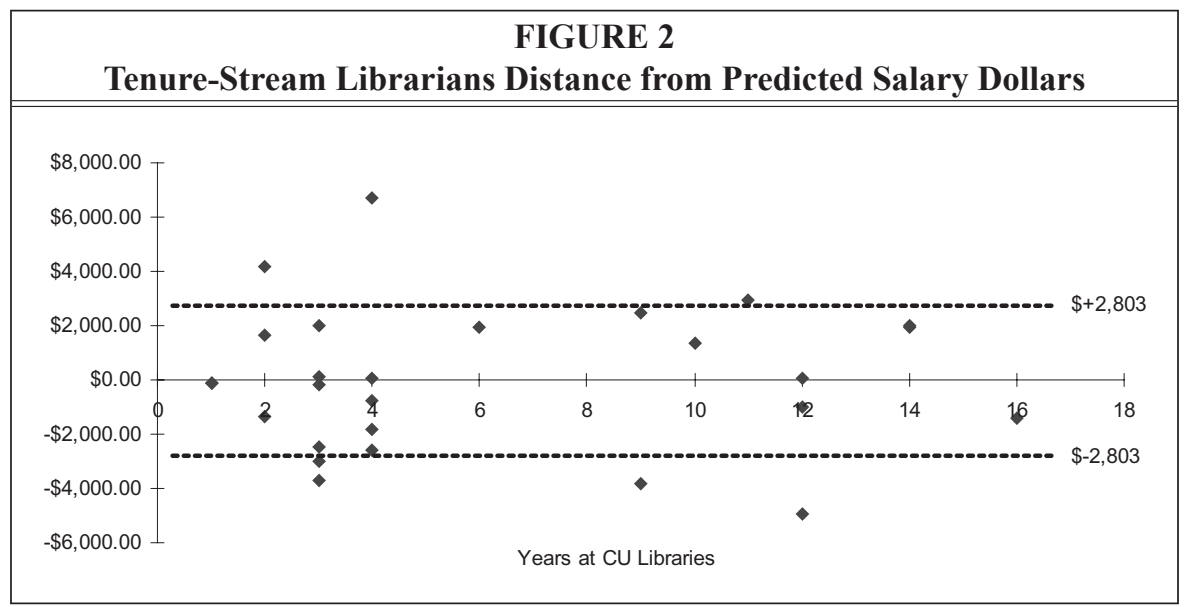

CU-Boulder Libraries, administrative responsibility, and above-average scholarly compensation will earn a salary of $\$ 71,733$ (from table 4). The actual salary of this librarian is $\$ 66,808$, resulting in a negative residual of $\$ 4,925$. Another tenure-stream example, observation number 16 , has four years at CU Libraries, no administrative responsibility, and above-average scholarly compensation. The regression model predicts a salary of $\$ 46,308$, while the actual salary is $\$ 53,000$, leaving a positive residual of $\$ 6,691$. While these two examples are the extremes, they do highlight that one librarian receives $\$ 6,691$ above the predicted salary while another receives $\$ 4,925$ below the predicted salary. This, however, does not mean that one is overpaid and the other is necessarily suffering from salary compression.

A better way to visualize this data is by charting the distance from the predicted salary (salary residuals) by the years at CU Libraries. Not only are patterns more easily recognized visually, but charts can also give a better sense of the magnitude of individual distances from the predicted salaries. Figures 2 and 3 chart the distance from the predicted salary for the tenurestream and senior instructor librarians. Each point represents one librarian with his/her years at CU on the horizontal axis and the distance from predicted salary on the vertical axis. The dashed lines on each illustration represent one standard error above and one standard error below the

\section{FIGURE 3}

\section{Senior Instructor Librarians Distance from Predicted Salary in Dollars}

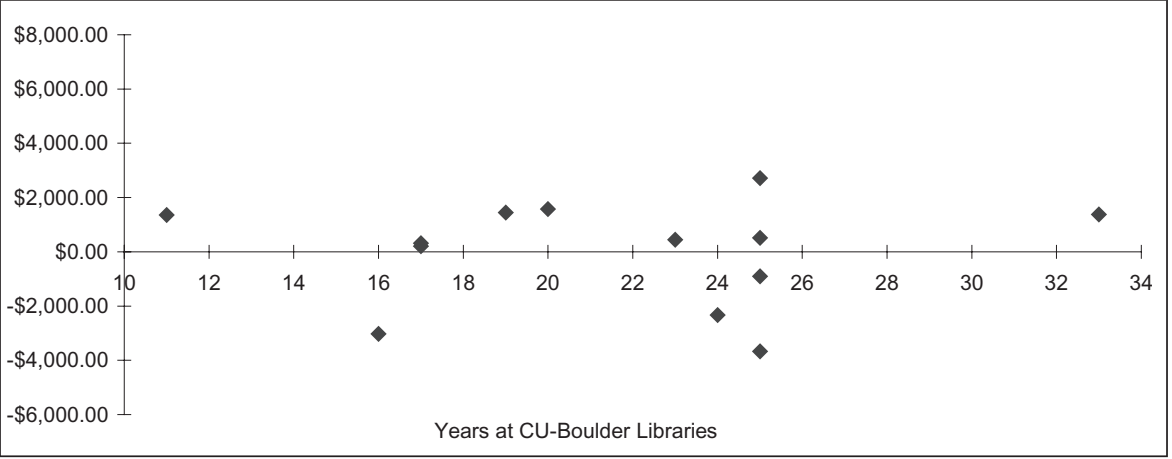


predicted salary. The standard error is a measure of the accuracy of the model itself. The regression statistic (table 2) predicted an overall error to the model of $\$ 2,803$ for the tenure-stream librarians. One way to express this is that one can be 95 percent confident that the true predicted salary is within \pm 2 standard errors, or $\pm \$ 2,803$, of the predicted salary. A librarian whose predicted salary is $\$ 44,611$ with a standard error of $\$ 2,803$ could fall anywhere in the range of $\$ 47,414$ and $\$ 41,808$. The dashed lines on the chart are a rudimentary way of representing the magnitude of standard error within the model, and, while not precisely accurate, they help to determine which individuals are potentially suffering from salary compression. Librarians falling between the dotted lines have salary residuals that can likely be explained by the error in the statistical model. For example, in illustration 6, the tenurestream librarian at the sixteen-year tick mark who is $\$ 1,438$ below the predicted salary axis falls within the standard error. This librarian probably would not qualify for a compensation adjustment based on salary compression. Those falling below the negative dashed line are candidates to be examined for salary compression. Neither the tenure-stream nor the senior instructor charts show any pattern of salary compression. In both charts, however, there are individuals falling below what can be explained by the standard error of the statistical model.

Illustration 6 charts the tenure-stream librarians' salary residuals. Although most tenure-stream librarians fall within the standard of error on the model, four librarians fall below the $\$ 2,803$ standard error. Two of the four librarians - each with only three years at CU-Boulder Libraries-are unlikely to be suffering from salary compression, as they are relatively new to the institution. The remaining two librarians, however, one with nine years and the other with twelve years at CU-Boulder, are potentially experiencing salary compression. There may be other circumstances that explain these two low salaries relative to their peers, but salary compression is a possibility.

The senior instructors' salary residuals are charted in illustration 7 . The standard error for the senior instructor model was $\pm \$ 2,240$, with two librarians falling significantly below one standard error. One librarian with sixteen years at CU-Boulder Libraries is $\$ 3,027$ below the predicted salary and another with twenty-five years at $\mathrm{CU}$ is $\$ 3,674$ below the predicted salary. What is particularly interesting is that, at the twenty-five-year point, there are four librarians who are statistically equivalent but range from $\$ 2,716$ above to $\$ 3,674$ below the predicted salary. As with the tenure-track librarians, there may be adequate explanations as to why the salaries are very different.

\section{Conclusions}

To identify potential salary compression, this study used multiple regression that statistically controlled for number of years at CU-Boulder Libraries, administrative responsibility, and compensation from scholarly productivity. Administrative responsibility represents a significant one-time salary increase that remains with the faculty member as long as he/she continues in the administrative position. Scholarly productivity is a significant component of annual salary increases, but the tenure-stream librarians and senior instructors produce research at very different rates. Because of this difference in scholarly output, the population was divided into two different pools. Of the forty librarians in the study, no pattern of compression was found, but evidence did indicate that four librarians - two senior instructors and two tenure-stream - may be impacted by salary compression.

While the statistical models developed for this study proved to be highly accurate, there are limitations to the precision of any statistical model, and there are underlying assumptions that can never adequately reflect the subtleties of a complex organization. For some 


\section{Estimating Salary Compression in an ARL Institution 403}

variables, such as number of years at CUBoulder Libraries, there is no doubt as to their accuracy. For other variables, such as administrative responsibility or compensation for scholarly productivity, the regression model was not as accurate in capturing their relation to salary compression. It is important to note, however, that no other published study has adequately captured such relationships. Equally important is an assumption about the homogeneity of assignments. In academic teaching departments, it is reasonable to presume that various faculty workloads and assignments are similar: each faculty member shares similar course loads and research assignments and has clearly defined administrative responsibilities. Making the same assumption about librarians would be to disregard the complexity of a research library. A digital initiatives librarian and a collection development librarian have different skills and different assignments and are not as interchangeable as faculty in teaching departments. Such distinctions, however important, cannot be captured in any statistical model. Expecting such clarity from a statistical model may be unrealistic. Instead, such models can determine if salary compression is pervasive within an organization or identify those individuals whom it might affect.

Finally, while unintentional salary compression may not produce immediate negative consequences, tracking its presence may provide warnings of potential trouble. Library administrators would benefit by being aware of the issues surrounding compression, recognizing any discriminatory compression early, and working to resolve it with the organization.

\section{Notes}

1. Debra E. Blum, "Colleges Worry That Newly Hired Professors Earn Higher Salaries Than Faculty Veterans," Chronicle of Higher Education 36 (Oct. 18, 1989): A1, 21.

2. Association of Research Libraries, "Table 2: Salary Trends in ARL University Libraries," Annual Salary Survey 2003-2004, 17.

3. Scott Seaman, "Salary Compression in the Association of Research Libraries," portal: Libraries and the Academy 5 (Jan. 2005): 77-91.

4. Julie K. Snyder, Gerald W. McLaughlin, and James R. Montgomery, "Diagnosing and Dealing with Salary Compression," Research in Higher Education 33 (Feb. 1992): 113-24.

5. Richard Huseman, W. Warren McHone, and Brian Rungeling, "Academic Salary Compression: A Productivity Model as a Remedy," Pubic Personnel Management 24 (Winter 1996): 453-65.

6. Nancy A. Bereman and Mark L. Lengnick-Hall, "Pay Compression at Public Universities: The Business School Experience," Public Personnel Management 23 (Fall 1994): 469-80.

7. Case studies following this pattern include A. Gary Dworkin, "The Salary Structure of Sociology Departments," American Sociologist 21 (Spring 1990): 48-59; Steven W. Lamb and William H. Moates, "A Model to Address Compression Inequities in Faculty Salaries," Public Personnel Management 28 (Winter 1999): 689-700; John Fraas, "Salary Compression and Noncompetitive Salaries: An Institution's Faculty Salary Assessment and Adjustment Program," (1999) ED438754; Marshall E. Drummond et al., "Dealing with Faculty Salary Inequity: A Case Study," (1994) ED373617.

8. Bereman and Lengnick-Hall, "Pay Compression at Public Universities"; Luis R. GomezMejia and David B. Balkin, "Pay Compression in Business Schools: Causes and Consequences," Compensation and Benefits Review 19 (Sept./Oct. 1987): 43-55; Allen L. Webster, "Demographic Factors Affecting Faculty Salary," Educational and Psychological Measurement 55 (Oct. 1995): 728-35.

9. Michael R. Ranson, "Seniority and Monopsony in the Academic Labor Market," American Economic Review 83 (Mar. 1993): 221-33.

10. Debra A. Barbezat, "A Loyalty Tax? National Measures of Academic Salary Compression," Research in Higher Education 45 (Nov. 2004): 761-76.

11. Seaman, "Salary Compression."

12. See Mike Aamodt, "Why Are There Five Million Types of Statistics?" Public Personnel Management 28 (Spring 1999): 157-61; Webster, "Demographic Factors Affecting Faculty Salary"; John W. Fraas, "Assessing Faculty Salary Compression: An Application of Two Methods," Mid-Western 
Educational Researcher 15 (Fall 2002): 28-32; William L. McCulley and Ronald G. Downey, “Salary Compression in Faculty Salaries: Identification of a Suppressor Effect," Educational and Psychological Measurement, 53 (Spring 1983): 79-86; Lamb and Moates, "A Model to Address Compression Inequities in Faculty Salaries."

13. See Kenneth M. Jennings and Frank S. McLaughlin, "Measuring and Correcting Inversion in Faculty Salaries at Public Universities," Public Personnel Management 26 (Fall 1997): 345.

14. James G. Strathman, "Consistent Estimation of Faculty Rank Effects in Academic Salary Models," Research in Higher Education 41 (Apr. 2000): 237-50.

15. Christopher B. Barrett and DeeVon Bailey, "Are Agricultural Experiment Station Faculty Salaries Competitively or Monopsonistically Determined?" Agricultural and Resource Economics Review 28 (April 1999): 1-10.

16. Debra A. Barbezat, "From Here to Seniority: The Effect of Experience and Job Tenure on Faculty Salaries," New Directions for Institutional Research 117 (Spring 2003): 21-47.

17. James Monks and Michael Robinson, "The Returns to Seniority in Academic Labor Markets," Journal of Labor Research 22 (Spring 2001): 415-27.

18. See William J. Moore, Robert J. Newman, and Geoffrey K. Turnball, “Do Academic Salaries Decline with Seniority?" Journal of Labor Economics 16 (Apr. 1998): 352-66.

19. Robert K. Toutkoushian, "Using Regression Analysis to Determine If Faculty Salaries Are Overly Compressed," Research in Higher Education 39 (Feb. 1998): 87-100.

20. Nicholas W. Twigg, Sean R. Valentine, and Rafik Z. Elias, "A Comparison of Salary Compression Models and Pay Allocation in Academia over Time, "The Review of Higher Education 26 (Fall 2002): 81-96.

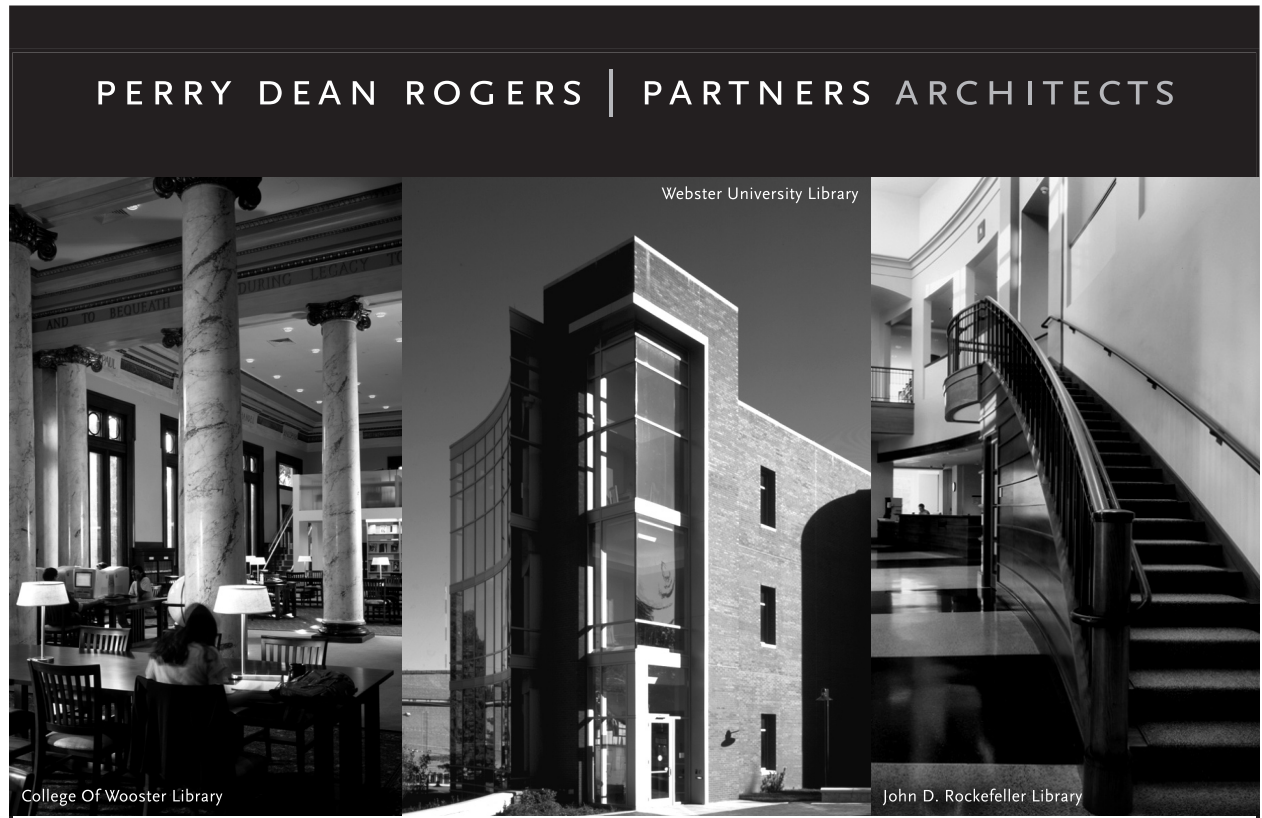

Designers for Libraries \& Academic Institutions

177 milk street boston massachusetts 02109 t 6174230100 f 6174262274 w perrydean.com 